\title{
SURVEY ON PERIPHYTIC FRESHWATER CYANOBACTERIA AND ALGAE IN THE SULTANATE OF OMAN
}

\author{
Ahmed A. El-Awamri and Adel F. Hamed* \\ Botany Department, Faculty of Science, Ain Shams University, Cairo, Egypt
}

\begin{abstract}
During the period of February 2004 to April 2005, 74 samples from various forms of algal vegetations were collected from different periphytic freshwater habitats in Sultanate of Oman. These habitats include water streams of Aflaj systems, springs, wadis and rocky mountain regions of El-Dakhilia, Al-Dhahirah, Al-Batinah, Al-Sharquyah, and Muscat. Thirty cyanobacterial taxa were identified based on their morphological characteristics. Distribution analysis of the cyanobacterial flora in correlation with the studied areas obviously emphasized that the locality of Al-Taeen was the richest site, while localities of Bahla, Al-Hamra, Wadi Al-Moudin, Wadi Tanouf in Nazwa were the poorest sites by the diversified cyanobacterial flora. The microscopic identification of the natural assemblages of the biotopes of the studied localities indicated the presence of seventeen taxa of chlorophytes. The autecology of green algae revealed that the appearance and existence of rhizobenthic Chara canescens and the unbranched filaments of Rhizoclonium heiroglyphieum strongly confirmed the hardness of water habitats of Jalan area in Al-Sharquyah. On the other hand, water habitats of Nazwa area were found to be the suitable environments favoring the growth and dominancy of freshwater periphytic chlorophytes. Fifteen diatom taxa were identified from the investigated localities. The autecology of the identified diatom taxa of oligohalobien type (indicators for freshwater habitats), except Biddulphia laevis and Achnanthes brevipes var. intermedia of mesohalobien type of salinity. This observation added strength conformity for the hardness of water of Jalan locality.
\end{abstract}

\section{Introduction}

Reports dealing with the occurrence of cyanobacteria and algae in arid environments have been known in different parts of the Middle East Area, in Egypt (Kobbia and El-Batanony 1975, El-Otify and Mahalel 2000 and Hamed 2003), in Saudi Arabia (Chantanchat and Bold, 1962; Mohsen and Bokhary, 1969 a, b; Abu-Zinada and El-Huseiny, 1975; Abou El-kheir, 1976; Aleem et al., 1982; Al-Homaidan and Arif, 1998) and in Sahara of North African countries Particularly Libya and Algeria (Compere, 1985).

Till now, no information is available about the periphytic freshwater cyanobacteria and algae in the Sultanate of Oman, even in the recent literature dealt with (the biology of the central desert of Oman, Ghazanfar, 2004).

*Corresponding author

(ISSN: 1110-8649) 
The purpose of this study is to publish the results of the preliminary survey on some of the localities of the unique desert environment of Oman.

\section{Materials and Methods}

\section{Study area}

The Sultanate of Oman is located at the southwest corner of the Arabian Peninsula and has an area of about 309500 sq.km. It is within the geographic block lying between latitudes $16^{\circ} 40 \mathrm{~N}$ and $27^{\circ} 20 \mathrm{~N}$ and Longitudes $51^{\circ} \mathrm{E}$ and $59^{\circ} 40 \mathrm{E}$. The climate of the country is hot and humid in summer (June $31-45^{\circ} \mathrm{C}$ ) and moderate in winter (January $20-25^{\circ} \mathrm{C}$ ). The country experiences an average rainfall of $100 \mathrm{~mm}$ over the entire area with extremes of $300 \mathrm{~mm}$ over northern mountain regions and $55 \mathrm{~mm}$ over the central part of Oman. About $82 \%$ of the country is mainly sand and gravel desert. The Sultanate of Oman has two main sources of water: traditional groundwater and non traditional water produced from high-tech desalination plants. The natural water sources of both surface and / or underground one are used for domestic and irrigation needs through system of aflaj (MWR 1993).

\section{Localities of samples collection}

During the period of February 2004 to April 2005, 74 samples from various forms of algal vegetations were collected from different habitats including water streams of Aflaj systems, springs, wadis and rocky mountain regions. The survey covered the main geographical regions of the Sultanate of Oman (Figure 1) as follows:

A- El-Dakhilia region (41 samples) which comprising the following localities:

1- Nazwa (Firq - Marfa Garden - Falj Dares - Al-Qarn Garden - Wadi Tanouf Manh). 2- Bahla. 3-Al-Hamra. 4- Izki. 5- Smail. 6- Birkat Al-Mouz. 7- AlGabbal Al-Akhdar. 8- Wadi Al-Moudin.

B- Al-Dhahirah region (3 samples) which comprising the locality of Ibri.

C- Al-Batinah region (13 samples) which comprising:

1- Nakhl. 2- Ain Al-Thoara

D- Al-Sharquyah region (14 samples) which comprising the following localities:

1- Jalan (Bani Abu Ali). 2- Al-Taeen. 3- Al-Mudhabi.

E- Muscat region (3 samples) which comprising the locality of Al-Quriate.

\section{Methods}

The samples were removed from their habitats using a sharp blade shovel or easily removed by hand. Samples were tipped into small cleaned plastic bottles and preserved in $4 \%$ formalin. Each sample was divided into two parts; one for preparing, identifying diatoms and the other for identifying the other cyanobacterial and algal species. The Jouse et al., (1949) method was used for cleaning diatom frustules. Identification of diatom groups was carried out by -170 - 
using Krammer and Lange-Bertalot (1986 and 1988) and Patrick and Reimer (1966 and 1975). Keys and literature used in the identification of cyanobacteria were Gollerbach et al., (1953); Desikachary (1959); Anagnostidis and Komarek (1985 and 1988) and Komarek and Anagnostidis (1986). Green algae were identified by using the key of Prescott (1961). Photomicrographs were taken for the most cleared species and plated in plates I, II and III.

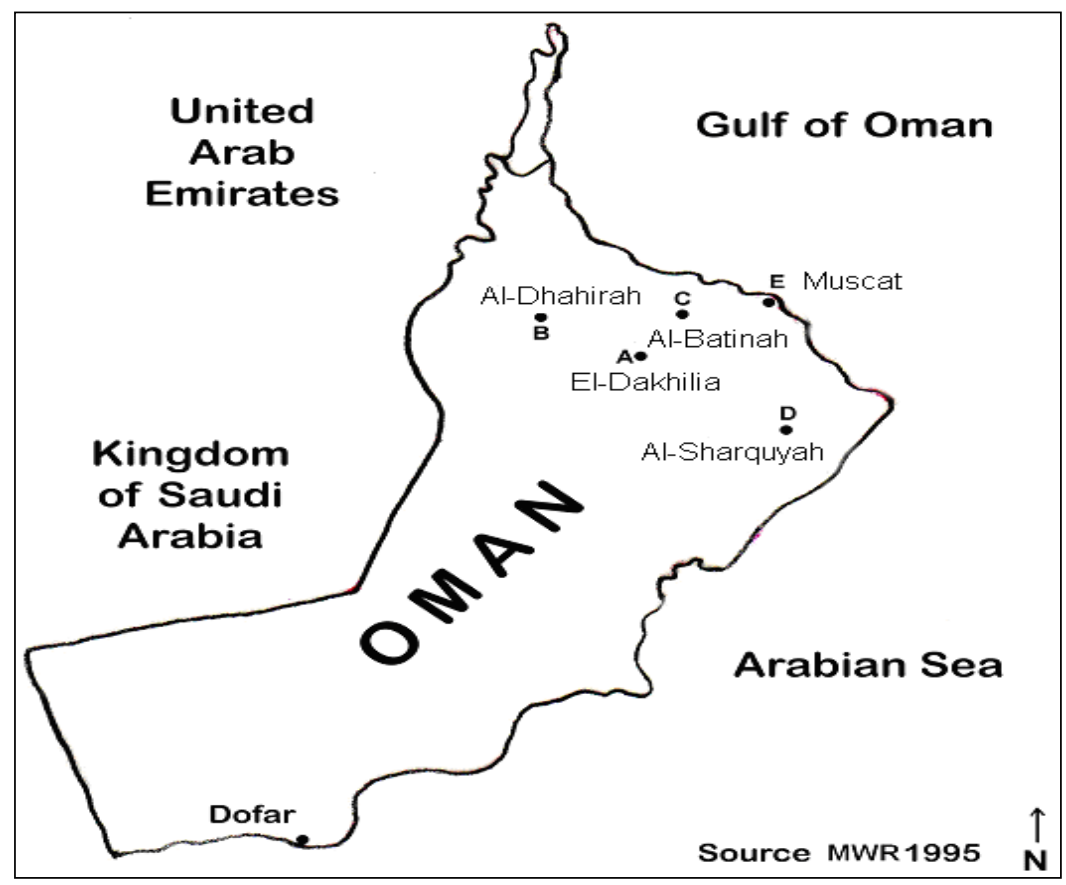

Figure (1): Localities of sample collection in the Sultanate of Oman

\section{Results and Discussion}

Throughout the period of investigation, various forms of algal vegetations were determined in different habitats including water streams of Aflaj systems, springs, wadis and rocky mountain regions in some localities of Oman.

\section{Cyanobacteria}

Natural water of Aflaj systems favoring the development of periphytic cyanobacteria. Thirty cyanobacterial taxa were identified based on their morphological characteristics. These were belonged to fourteen genera of three orders and five families (Table 1). In particular, twelve species of genus Oscillatoria were recorded from the total number.Regarding to the distribution of 
the cyanobacterial taxa along the investigated localities, it was apparent that, Gloeocapsa turgida was the highly distributed taxon. Cyanoprocaryotes of Gloeocapsa minor, Synechocystis aquatilis, Synechocystis pevalekii, Gomphosphaeria aponina, Oscillatoria geminate, Oscillatoria jasorvensis, Oscillatoria proboscidea, Oscillatoria subbrevis, Oscillatoria tenuis, Microcoleus chthonoplastes, Homoeothrix Juliana and Calothrix braunii, each one was monospecific entity for certain geographical locality.

The habitat of Ain Al-Thoara spring was reflected the dominancy of some of chroococcean taxa (Gloeocapsa turgida, Aphanothece nidulans, Merismopedia tenuissima) and non-heterocystous filamentous forms of Oscillatoria laete-virens, Oscillatoria obscura, Lyngbya martensiana and Stichosiphon sansibaricus.

The topographical features (wadis, plains and mountains), their habitats are mainly of sand and gravel desert that receiving water of rainfall, making small water ditches and mountain streams. The cyanobacterial flora was composed of one chroococcean taxon of Gloeocapsa decorticans. One entophysalidacean form of Chlorogloea microcystoides and two species of oscillatorian, Oscillatoria claricentrosa and Oscillatoria subbrevis.

Distribution and frequency analysis of the cyanobacterial flora in correlation with the studied areas obviously emphasized that the locality of Al-Taeen was the richest site, while localities of Bahla, Al-Hamra, Wadi Al-Moudin, Wadi Tanouf were the poorest sites by the diversified cyanobacterial flora.

In general, cyanobacteria considered as one of the desert ecosysytems (Bhatnagar and Bhatnagar, 2005), dominating in sandy-saline desert (GarciaPichel et al., 2001), due to their forms are physiological resistance to desiccation, intense illumination and temperature extremes (Potts, 1994; Hawkes and Flechtner, 2002). All taxa are cosmopolitan; some of these taxa were previously recorded in the algal flora of Saudi Arabia (Abou El-Kheir et al., 1976) and Egypt (El-Awamri et al., 1996; Hamed, 2001 and 2003).

\section{Chlorophytes}

The microscopic identification of the natural assemblages of the biotopes of the studied localities indicated the presence of seventeen taxa of chlorophytes (Table 1). The recorded green algae were belonged to six orders of Volvocales, Chlorococcales, Cladophorales, Oedogoniales, Conjugales and Charales. The main bulk of the productivity of chlorococcal type. The two filamentous forms of Oedogonium (Oedogonium $\mathrm{sp}_{1}$ and Oedogonium $\mathrm{sp}_{2}$ ) and the one species type of Spirogyra were identified to the level of genus because vegetative structures were not bearing the sexual stage (zygote formation), which is the main discriminating feature used in the identification to the level of species or variety. Richly branched filaments of Cladophora glomerata were highly distributed in the most of the 
investigated localities together with the unbranched filaments of Rhizoclonium implexum. Cells of Cladophorales secrete mucilage and this is probably one of the main reasons why are often loaded with epiphytes (Fritsch, 1935). Consequently, the above mentioned phenomenon interpreted the epiphytic colonization of Cladophora and Rhizoclonium filaments by the two cyanobacterial epiphytes of Chroococcus cohaerens and Stichosiphon sansibaricus respectively.

The appearance and existence of rhizobenthic Chara canescens and the unbranched filaments of Rhizoclonium heiroglyphieum strongly confirmed the hardness of water habitats of Jalan area. On the other hand, water habitats of Nazwa area were found to be the suitable environments favoring the growth and dominancy of freshwater periphytic chlorophytes such as Pandorina morum, Pediastrum duplex, Ankistrodesmus falcatus, Selenastrun sp, Franceia tuberculat, Senedesmus bijugatus and Mougeotia quadrangulata (Lewis and Flechner, 2002).

\section{Bacillariophytes}

Fifteen diatom taxa were identified from the investigated localities. One taxon was belonging to Class Centrophyceae, while the rest were belonging to Class Pennatophyceae. The autecology of the identified diatom taxa of oligohalobien type (indicators for freshwater habitats), except Biddulphia laevis and Achnanthes brevipes var. intermedia of mesohalobien type of salinity (indicators for brackish water habitats) (Kolbe, 1932 ;Hustedt, 1959; Ehrlish, 1975). The previous observation added strength conformity for the hardness of water of Jalan locality that favoring the appearance of mesohalobien diatom taxa, together with the rhizobenthic charoid taxon Chara canescens and the unbranched green filaments of Rhizoclonium heiroglyphieum.

The quantitative analysis of diatom taxa along the the investigated sites, revealed that some localities having unique feature of dominancy by certain diatom species as follows: 1-Biddulphia laevis and Achnanthes brevipes var. intermedia were the most dominating taxa of Jalan loaclity. 2-samples of the mountain streams of Al-Gabal Al-Akhdar obviously indicated the dominancy by the freshwater entities of Synedra ulna, Achnanthes minutissima, Cymbella ventricosa and Nitzschia filiformis. 3- Cocconeis placentula was the most common diatom which attained its dominancy as epiphytic on the filaments of Cladophora glomerata in Wadi Al-Moudin locality. 4- The site of Al-Quriate, revealed the dominancy by Gyrosigma acuminatum and Cymbella turgida. 5Synedra rumpens and Nitzschia fonticola were considered as monospecific diatom features for Manh and Ibri localities respectively.

\section{Pyrrophytes}

One taxon of the cated dinoflagellate (Peridinium $\mathrm{sp}$ ) was identified in the samples of Al-Quriate during March, 2005 as a dominant pyrrophyte.

Egyptian J. of Phycol. Vol. 6, 2005 - 173 - 
Table (1): Records of cyanobacteria and algae in some of the geographical localities in the Sultanate of Oman.[A- El-Dakhilia region: 1- Nazwa (Firq, Marfa Garden, Falj

Dares, Al-Qarn Garden, Wadi Tanouf, Manh. 2- Bahla. 3-Al-Hamra. 4- Izki. 5- Smail. 6- Birkat Al-Mouz. 7- Al- Gabbal Al-Akhdar. 8- Wadi Al-Moudin . B- Al-Dhahirah region:

9-Ibri. C- Al-Batinah region: 10- Nakhl. 11- Ain Al-Thoara. D- Al-Sharquyah region:

12- Jalan (Bani Abu Ali). 13- Al-Taeen. 14- Al-Mudhabi. E- Muscat region 15- Al-Quriate]

\begin{tabular}{|c|c|c|c|c|c|c|c|c|c|c|c|c|c|c|c|}
\hline Localities taxa & 1 & 2 & 3 & 4 & 5 & 6 & 7 & 8 & 9 & 10 & 11 & 12 & 13 & 14 & 15 \\
\hline \multicolumn{16}{|c|}{ Cyanobacteria } \\
\hline Genus Chroococcus Nag. & & & & & & & & & & & & & & & \\
\hline C. cohaerens (Breb.) Nag. & + & & & & & & & + & & & & & & + & \\
\hline \multicolumn{16}{|l|}{ Genus Gloeocapsa Kütz. } \\
\hline G. decorticans Kütz. & + & & & & + & & + & & & & & & & & \\
\hline G. gelatinosa Kütz & & & & & & & & & & & & & + & + & \\
\hline G. turgida (Kütz.) Hollerb & + & & & & & & & + & & + & + & & & + & \\
\hline G. minor (Kütz.) Hollerb & + & + & & & & & & & & & & & & & \\
\hline \multicolumn{16}{|l|}{ Genus Aphanothece Nag. } \\
\hline A. nidulans Richter, P. & & & & & & & & & & & + & + & & & \\
\hline \multicolumn{16}{|l|}{ Genus Synechocystis Sauvageau } \\
\hline S. aquatilis Sauv. & & & & & & & & & & & & & + & & \\
\hline S. pevalekii Erecgovic & & & & & & & & & & & & & + & & \\
\hline \multicolumn{16}{|l|}{ Genus Merismopedia Meyen } \\
\hline M. glauca (Ehr.) Nag. & + & & & + & & & & & & & & & + & & \\
\hline M. tenuissima Lemm. & + & & & & & & & & & & & & & & + \\
\hline \multicolumn{16}{|l|}{ Genus Gomphosphaeria Kütz. } \\
\hline G. aponina Kütz. & & & & & & & & & & + & & & & & \\
\hline \multicolumn{16}{|l|}{ Genus Chlorogloea Wille } \\
\hline C. microcystoides Kütz. & + & & & & & & + & & & & & & + & & \\
\hline \multicolumn{16}{|l|}{ Genus Stichosiphon Geitler } \\
\hline $\begin{array}{l}\text { S. sansibaricus (Hieron) Drout et } \\
\text { Daily }\end{array}$ & + & & & & & & & & & & & & & & \\
\hline \multicolumn{16}{|l|}{ Genus Oscillatoria Vaucher } \\
\hline O. claricentrosa Gardner & + & & & & & & + & & & & & & & & \\
\hline O. geminate Menegh & & & & & & & & & & & & & + & & \\
\hline O. jasorvensis Vouk & & & & & & & & & + & & & & & & \\
\hline O. laete-virens (Crouan) Gomont & + & & & & & & & & & & & & & & \\
\hline O. major Vaucher & + & & & & & & & & & + & & & & & \\
\hline O. obscura Bruhl et Biswas & + & + & & & & & & & & & + & & & & \\
\hline O. proboscidea Gomont & & & & & & & & & & & & & & + & \\
\hline O. sancta (Kütz) Gomont & + & & & & & & & & & & & & + & & \\
\hline O. splendida Grev. ex Gomont & + & & + & & & & & & & & & & & & + \\
\hline O. subbrevis Schmidle & + & & & & & & + & & & & & & & & \\
\hline O. subtillisima Kütz ex De Toni & + & & & & & & & & & + & & & & & \\
\hline O. tenuis Agardh ex Gomont & + & & & & + & & & & & & & & & & \\
\hline \multicolumn{16}{|l|}{ Genus Lyngbya Agardh } \\
\hline $\begin{array}{l}\text { L. martensiana Menegh. ex } \\
\text { Gomont }\end{array}$ & + & & & & & & & & & & & + & & & \\
\hline \multicolumn{16}{|l|}{ Genus Microcoleus Desm. } \\
\hline \multicolumn{16}{|l|}{$\begin{array}{l}\text { M. chthonoplastes Thuret ex } \\
\text { Gomont }\end{array}$} \\
\hline \multicolumn{16}{|l|}{ Genus Nostoc Vaucher } \\
\hline \multicolumn{16}{|l|}{$\begin{array}{l}\text { N. calcicola Breb. ex Born. et } \\
\text { Flah }\end{array}$} \\
\hline \multicolumn{16}{|l|}{ Genus Homoeothrix (Thuret) Kirchn. } \\
\hline H. Juliana (Menegh.) kirchnev. & + & & & & & & & & & & & & & & \\
\hline
\end{tabular}

-174 - 
Survey on Periphytic Freshwater Cyanobacteria and Algae in the Sultanate of Oman

\begin{tabular}{|c|c|c|c|c|c|c|c|c|c|c|c|c|c|c|}
\hline Genus Calothrix Agardh & & & & & & & & & & & & & & \\
\hline C. braunii (A. Br.) Born et Flah & + & & & & + & & & & & & & & & \\
\hline \multicolumn{15}{|c|}{ Chlorophyta } \\
\hline Genus Pandorina Bory & & & & & & & & & & & & & & \\
\hline P. morum (Muell.) Bory & + & & + & & & & & & & & & & & \\
\hline Genus Pediastrum Meyen & & & & & & & & & & & & & & \\
\hline P. duplex Meyen & + & & & & & & & & & & & & & \\
\hline Genus Ankistrodesmus Corda & & & & & & & & & & & & & & \\
\hline A. falcatus (Corda) Ralfs & + & & & & & & & & & & & & & \\
\hline Genus Selenastrum Reinsch & & & & & & & & & & & & & & \\
\hline S. sp & + & & & & & & & & & & & & & \\
\hline Genus Franceia Lemm. & & & & & & & & & & & & & & \\
\hline F. tuberculata & + & & & & & & & & & & & & & \\
\hline Genus Scenedesmus Meyen & & & & & & & & & & & & & & \\
\hline S. bijugatus (Turpin) Kütz. & + & & + & & & & & & & & & & & \\
\hline S. obliquus Kütz. & & & & & & & & & & & & & & + \\
\hline Genus Rhizoclonium Kütz. & & & & & & & & & & & & & & \\
\hline R. fontanum Kütz. & & & & & & & & & & & + & & & \\
\hline $\begin{array}{l}\text { R. heiroglyphieum (C. a. Ag.) } \\
\text { Kütz. }\end{array}$ & & & & & & & & & & & + & & & \\
\hline R. implexum (Dillwyn) Kutz. & + & + & & + & + & + & + & & & & & & & + \\
\hline Genus Cladophora Kütz. & & & & & & & & & & & & & & \\
\hline C. glomerata (L.) Kütz. & + & & + & + & & & + & + & + & + & & & & \\
\hline Genus Oedogonium Link & & & & & & & & & & & & & & \\
\hline$O . \mathrm{sp}_{1}$ & + & & & + & + & & & & + & & & & & + \\
\hline$O . \mathrm{sp}_{2}$ & + & & & + & & & & & & & & & + & + \\
\hline Genus Cosmarium Corda & & & & & & & & & & & & & & \\
\hline C. granatum Breb. ex Ralfs & + & & + & & & & & & & & & & & \\
\hline C. subimpressulum Borge & + & & & & & & + & & & & & & & \\
\hline Genus Spirogyra Link. & & & & & & & & & & & & & & \\
\hline S. sp & + & & & + & & & & & & + & & & & \\
\hline Genus Chara Linnaeus & & & & & & & & & & & & & & \\
\hline $\begin{array}{l}\text { C. canescens Loiseheur- } \\
\text { Deslongchamps }\end{array}$ & & & & & & & & & & & + & & & \\
\hline & & & & cills & riop & ayta & & & & & & & & \\
\hline Genus Biddulphia Gray & & & & & & & & & & & & & & \\
\hline B. laevis (E.) Hust. & & & & & & & & & & & + & & & \\
\hline Genus Synedra Ehr. & & & & & & & & & & & & & & \\
\hline S. rumpens Kütz. & + & & & & & & & & & & & & & \\
\hline S. ulna (Nitzsch) Ehr. & + & & & & & & + & + & & + & & & & + \\
\hline Genus Achnanthes Bory & & & & & & & & & & & & & & \\
\hline A. affinis Grun. & & & & & & & & & & + & + & & & \\
\hline A. brevipes var. intermedia Kütz. & + & + & & & & & & & & & + & & & \\
\hline A. minutissima Kütz. & + & + & & & & & + & & & & & & & \\
\hline Genus Cocconeis Ehr. & & & & & & & & & & & & & & \\
\hline C. placentula Ehr. & + & & & & & & & + & & & & & & \\
\hline Genus Amphora Ehr. & & & & & & & & & & & & & & \\
\hline A. pediculus Kütz. & & & & & & & & & & & & + & + & \\
\hline Genus Gyrosigma Hassall & & & & & & & & & & & & & & \\
\hline G. acuminatum (Kütz.) Rabenh. & & & & & & & & & & & & & & + \\
\hline Genus Cymbella Ag. & & & & & & & & & & & & & & \\
\hline C. affinis Kütz. & + & & & & & & & + & & + & & & & \\
\hline C. turgida (Greg.) Cl. & & & & & & & & & & & & & & + \\
\hline C. ventriccosa Kutz. & + & & & & & & + & & & & & & & \\
\hline Genus Gomphonema Ag. & & & & & & & & & & & & & & \\
\hline
\end{tabular}


Ahmed A. El-Awamri and Adel F. Hamed

\begin{tabular}{|l|c|c|c|c|c|c|c|c|c|c|c|c|c|c|c|}
\hline G. parvulum Kütz. & + & & & + & & & + & & & + & & & & & \\
\hline Genus Nitzschia Hassall & & & & & & & & & & & & & & & \\
\hline N. filiformis (W.sm.) Hust. & + & & & & & & + & & & & & & & & \\
\hline N. fonticola Grun. & & & & & & & & & & & & \\
\hline
\end{tabular}

$-176-$ 


\section{Plate I}

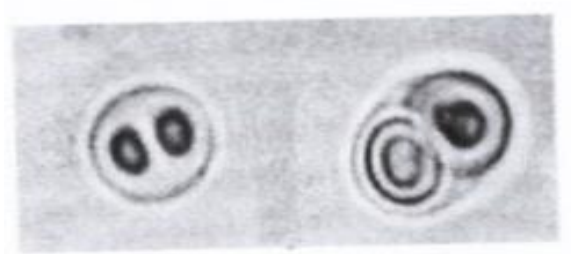

1

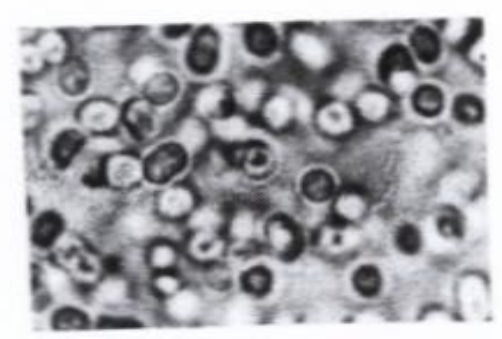

4

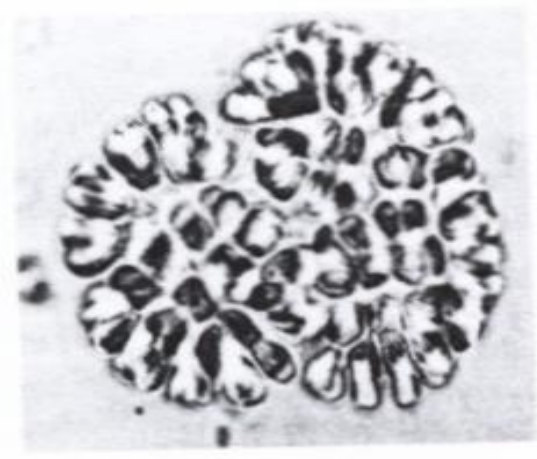

6
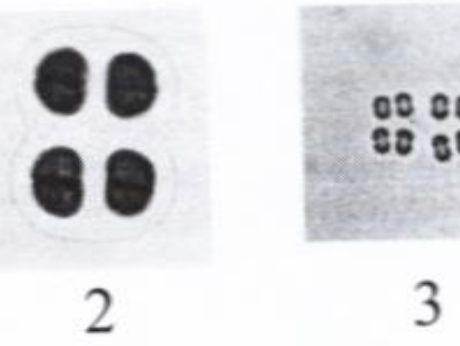

$\log _{80} 00$

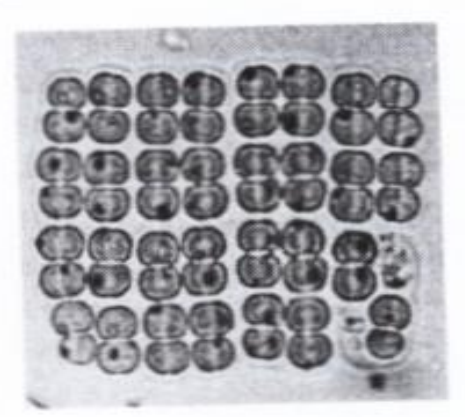

5

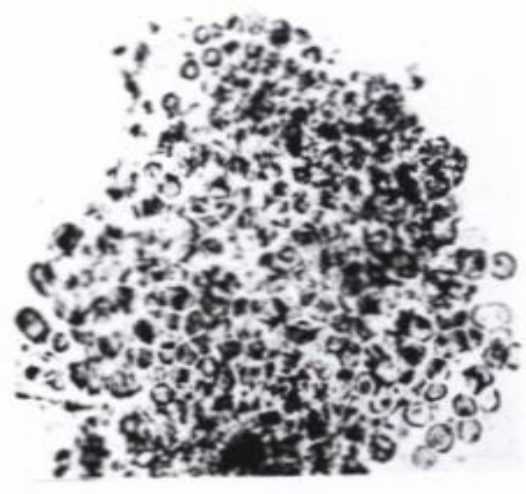

7

1- Gloeocapsa gelatinosa Kütz(600X);2- Gloeocapsa turgida (Kütz.) Hollerb (600X); 3-Gloeocapsa minor (Kütz.) Hollerb (600X); 4- Synechocystis pevalekii Erecgovic (1500X); 5- Merismopedia glauca (Ehr.) Nag. (700X); 6- Gomphosphaeria aponina Kütz. (450X);7-Chlorogloea microcystoides Kütz. (700X). 
Ahmed A. El-Awamri and Adel F. Hamed

\section{Plate II}
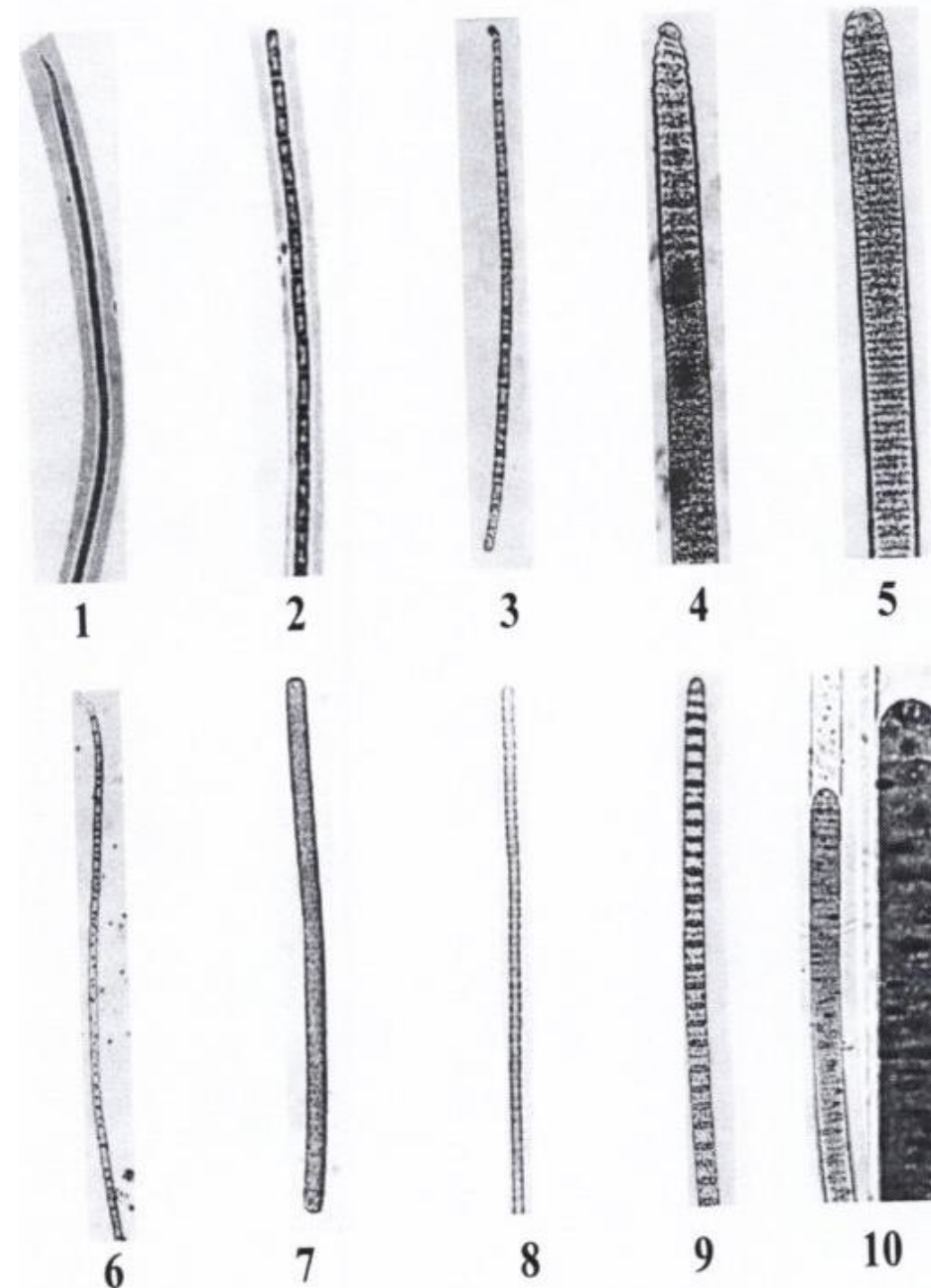

1

2

3

4

5

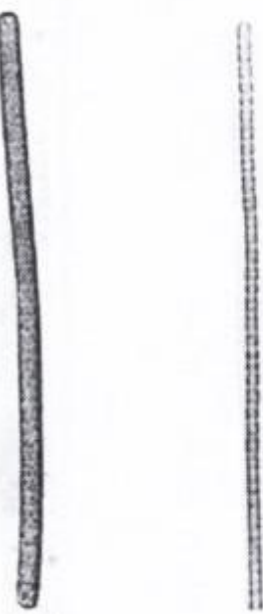

글

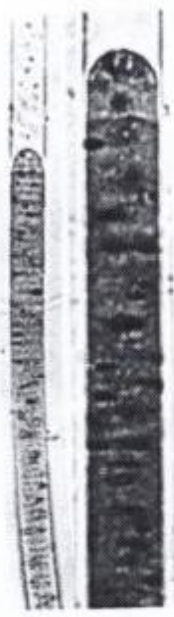

6

7

8

9

10

1- Oscillatoria claricentrosa Gardner (600X); 2- Oscillatoria geminate Menegh (1000X); 3- Oscillatoria jasorvensis Vouk (700x); 4- Oscillatoria proboscidea Gomont (600X); 5- Oscillatoria sancta (Kütz) Gomont (600x); 6- Oscillatoria splendida Grev. ex Gomont (750X); 7- Oscillatoria subbrevis Schmidle (400X); 8- Oscillatoria subtillisima Kütz ex De Toni (700X); 9- Oscillatoria tenuis Agardh ex Gomont (700X); 10- Lyngbya martensiana Menegh. ex Gomont (600X-1500X). 


\section{Plate III}

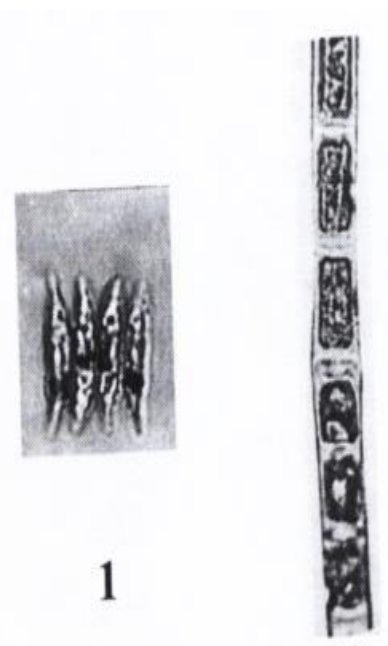

2
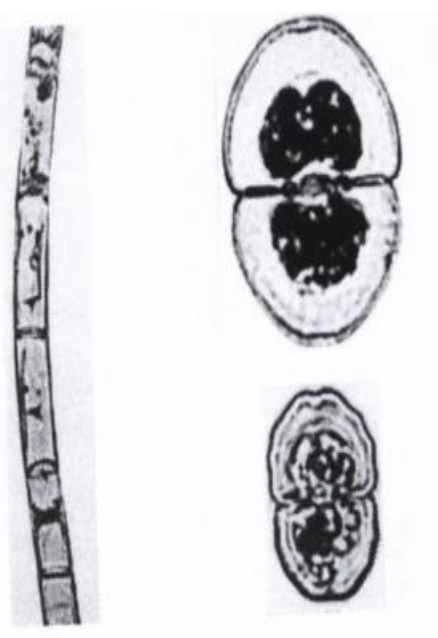

4

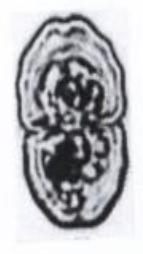

5

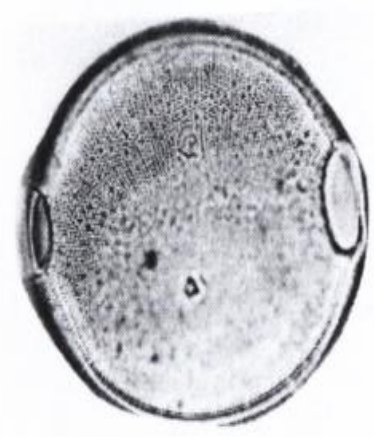

6

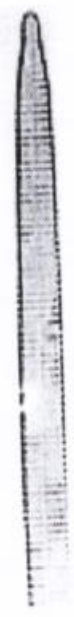

7
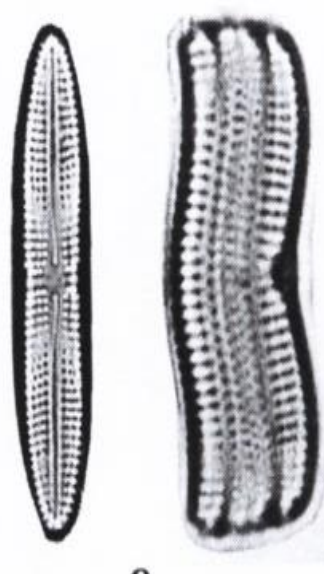

8
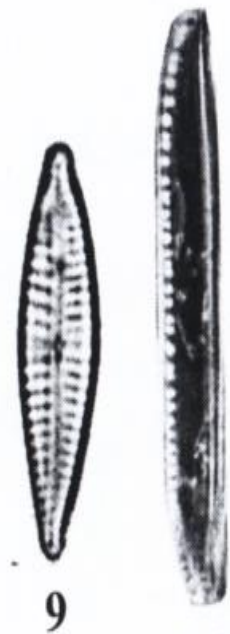

10

1- Scenedesmus obliquus Kütz. (400X); 2- Rhizoclonium implexum (Dillwyn) Kütz. (400X); 3- Oedogonium $\mathrm{Sp}_{1}$ (400X); 4-Cosmarium granatum Breb. ex Ralfs (800X); 5- Cosmarium subimpressulum Borge (700X); 6- Biddulphia laevis (E.) Hust. (1000X);

7- Synedra ulna (Nitzsch) Ehr. (1300X); 8-Achnanthes brevipes var. intermedia Kütz. (1500X); 9- Gomphonema parvulum Kütz. (1500X); 10-Nitzschia filiformis (W.sm.) Hust. (1700X).

Egyptian J. of Phycol. Vol. 6, 2005 


\section{References}

Abou El-Kheir, W. S. (1976). Notes on the distribution of algal flora in ElGemaih and El-Kharg, Riyadh, Saudi Arabia. Ann. Rev. Univ. Coll. For Girls, Ain Shams Univ., 9: 69-75.

Abu-Zinada, A. H. and El-Huseiny, T. H. (1975). Seasonal variations of soil microflora and their activities in Riyadh region, Saudi Arabia: Part 1: Algae.

Al-Homaidan, A. A. and Arif, I. A. (1998). Ecology and bloom-forming algae of a semi-permanent rain-fed pool at Al-Kharj, Saudi Arabia. J. Arid Environments, 38: 15-25.

Aleem, A. A.; Khafaje, A. K. and Al-Bassam, B. A. (1982). An algal community from hot springs at Al-Qaseem, Saudi Arabia: short communication . Bull. Fac. Sci. King Abdulaziz Univ., Jeddah, Saudi Arabia, 6: 73-75.

Anagnostidis, K. and Komárek, J. (1985). Modern approach to the classification system of cyanophytes. 1- Introduction. Arch. Hydrobiol. Suppl. 71, 1/2 Algological Studies, 38/39:291-30.

Anagnostidis, K. and Komárek, J. (1988). Moderm approach to the classification system of cyanophytes. 3- Oscillatoriales. Arch. Hydrobiol. Suppl. 80 Algological Studies, 50/53: 327-372.

Bhatnagar, A. and Bhatangar, M. (2005). Microbial diversity in desert ecosystems. Current Science, 98(1): 91-100.

Chantanchat, S. and Bold, H. C. (1962). Phycological studies. II. Some algae from arid soil. The University of Texas, Publication No. 6218.

Compere, P. (1985). Taxonomy and distribution of Saharan Cyanophyta. Arch. Hydrobiol. Suppl.7, 1/2 (Algological Studies), 38/39:351-360.

Desikachary, T. V. (1959). Cyanophyta. New Delhi. Indian Council Agricultural Research, 686 pp.

Ehrlish, A. (1975). The diatoms from the surface sediments of the Bardawil Lagoon (Northern Sinai)-Paleaoecological significance. Nova Hedwigia Beihft, 53: 253-277.

El-Awamri, A. A. Shaaban, A. S. and Hamed, A. F. (1996). Algae in Saint Catherine region (South Sinai) Egypt. Egyp. J. Bot., 36: 145-168.

El-Otify, A. M. and Mahalel, U. A. (2000). Ecological studies on the soil algae of Wadi Allaqi biosphere reserve area in south eastern desert, Egypt. Egypt. J. Phycol. 1: 107-119.

Fritsch, F. E. (1935). The structure and reproduction of algae. Vol. I, Cambridge Uiversity Press.

Garcia-Pichel, F.; Lopez-Cortes, A. and Naubel, U. (2001). Phylogenetic and morphological diversity of cyanobacteria in soil desert crusts from the Colorado plateau. Appl. Env. Microbiol., 67: 1902-1910. 
Ghazanfar, S. A. (2004). Biology of the central desert of Oman. Turk. J. Bot., 28: 65-71.

Gollerbach, M. M.; Koscinckaja, E. K. and Polanskii, V. I. (1953). Freshwater algae of USSR Vol. 2. Cyanophyta. Pub. "Sauv. Nauke" Moscow, 652 pp.

Hamed, A. F. (2001). Geographical distribution of aquatic and soil algae of Wadi Gharandel, Southwest Sinai , Egypt. Az. J. Microbiol., 53: 54-77.

Hamed, A. F. (2003). Cyanobacteria and algal flora of Wadi El-Taal desert, AbuZenima area, South Sinai. Egyptian J. Phycol., 4(2): 203-212.

Hawkes, C. V. and Flechtner, V. R. (2002). Biological soil crusts in xeric Florida shrubland: composition, abundance, and spatial heterogeneity of crusts with different disturbance histories. Microb. Ecol., 43: 1-12.

Hustedt, F. (1959). Die Diatomeenflora des Fluss-Systems der weser in Gebiet der Hansestadt Bremen. Abh. Naturw. Ver Bremen, 34: 181-440.

Jouse, A. P.; Proschkina-Laverenko, A. I. and Sheshykova, V. C. (1949). Diatom Analysis Vol. 1 Pub. Geol. Liter. Leningrad, 339 pp.

Kobbia, I. A. and El-Batanouny, K. H. (1975). Studies on the algal flora of Egyptian soil. I. Different sites along a lake in the salines of Wadi ElNatrun. Pub. Cairo Univ. Herb., 6: 61-72.

Kolbe, R. W. (1932). Grundhinien einer algemeinen okologies der Diatomeen. Erge bnisseder Biologie. Berlin., 8: 221-348.

Komárek, J. and Anagnostidis, K. (1986). Modern approach to the classification system of cyanophytes. 2- Chroococcales. Arch. Hydrobiol. Suppl., Algological Studies, 73: 157-226.

Krammer, K. and Lange-Bertalot, H. (1986). Bacillariophyceae, Naviculaceae. Gustav Fisher Verlag. Stuttgart, New York, 876 pp.

Krammer, K. and Lange-Bertalot, H. (1988). Bacillariophyceae, Nitzschiaceae. Gustav Fisher Verlag. Stuttgart, New York. 821pp.

Lewis, L. A. and Flechner, V. R. (2002). Green algae (Chlorophyta) of desert microbiotic crusts: diversity of North American Taxa. Taxon, 443-451.

Ministry of Water Resources (MWR), Oman. (1993). Inventory Operations Manual, $1^{\text {st }}$ edition, National Well Inventory.

Ministry of Water Resources (MWR), Oman. (1995). Water Resources of Sultanate of Oman and Introductory Guide.

Mohsen, A. F. and Bokhary, H. A. (1969 a). A study of distribution and periodicity of fresh water algae in Riyadh area as related to environment. Bull. Fac. Sci. Riyadh Univ., 1: 2-57.

Mohsen, A. F. and Bokhary, H. A. (1969 b). Studies on four fresh water algae from Riyadh district grown under controlled cultural conditions. Bull. Fac. Sci., Riyadh Univ., 1: 58-119.

Patrick, R. and Reimer, C. W. (1966). The diatoms of the United States-Acad. Nat. Sci. Philadelphia. Monograph, 13(1): 1-688.

Patrick, R. and Reimer, C. W. (1975). The diatoms of the United States-Acad. Nat. Sci. Philadelphia. Monograph, 13(2,1): 1-213.

Egyptian J. of Phycol. Vol. 6, $2005 \quad-181$ - 
Potts, M. (1994). Desiccation tolerance of prokaryotes. Microbiol. Rev., 58: 755805.

Prescott, G. W. (1961). Algae of the Western Great Lakes Area. Wm. C. Brown Publisher, Dubuque, Iowa, U.S. A., 977 pp.

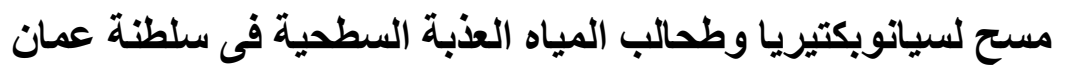

أحمد عبد الرحمن العوامري و عادل فهمي حامد

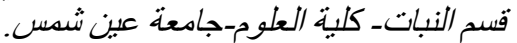

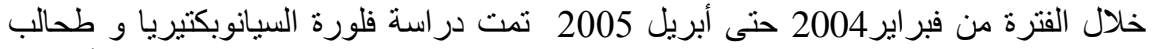

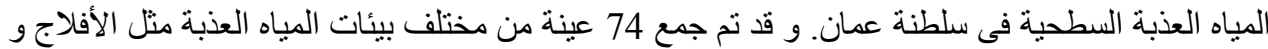

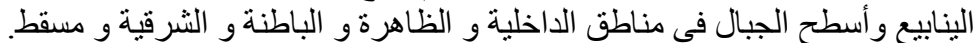

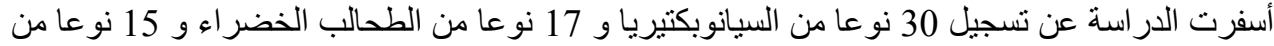

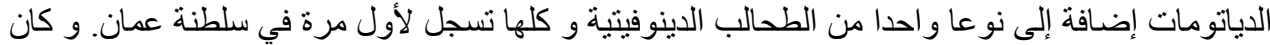

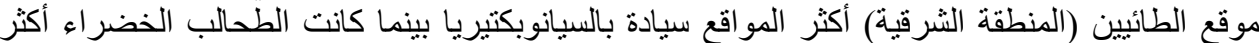

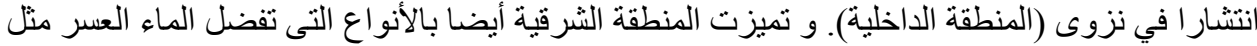
Rhizoclonium heiroglyphieum و Chara canescens Achnanthes brevipes var. intermedia و Biddulphia laevis 